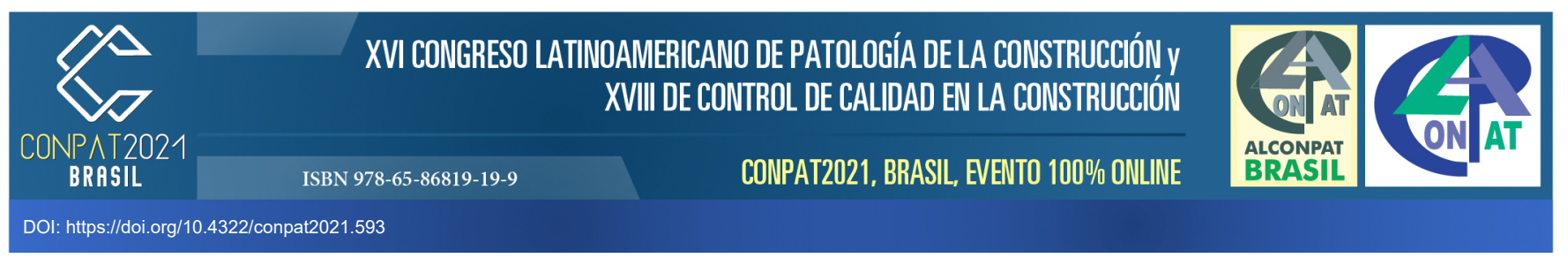

\title{
Probability of corrosion initiation in RC structures by chlorides - Case study of a Pier in Brazil
}

\author{
M. Barbosa ${ }^{1 *}$, D. Val $^{2}$ \\ *Autor de Contacto: maxtimo@globo.com \\ DOI: se asigna al publicar el artículo
}

\footnotetext{
${ }^{1}$ Civil and Environmental Engineering Department, University of Brasília, Brasília, Brazil.

${ }^{2}$ Institute for Infrastructure \& Environment, Heriot-Watt University, Edinburgh, Scotland
}

\section{RESUMEN}

Este estudio de caso pretende estimar la probabilidad de inicio de corrosión con cloruro a lo largo del tiempo en un muelle de concreto reforzado construido en Brasil en 2005. Se realizó un enfoque de confiabilidad utilizando la ayuda de Microsoft Excel Visual Basic (VBA), por medio de simulaciones de Monte Carlo. Se aplicó un modelo semi-empírico basado en fib (2006). Los resultados muestran una capacidad de servicio inadecuada del muelle durante su vida de diseño. Se observó que la probabilidad de inicio de corrosión depende en gran medida de la concentración de cloruro en la superficie. Estos resultados utilizando datos de 2010 implican que el mantenimiento temprano de las estructuras marinas puede ser más económico, pero nuevas mediciones de la concentración de cloruro en la superficie implicarían resultados diferentes,. Este documento es un punto de referencia para el diseño futuro de estructuras marinas.

Palabras Clave: Estructuras de Hormigón Armado; Corrosión del cloruro; confiabilidad; Monte Carlo.

\section{Probability of corrosion initiation in RC structures by chlorides - Case study of a Pier in Brazil}

\begin{abstract}
This case study intends to estimate the probability of chloride-corrosion initiation over time in a reinforced concrete pier constructed in Brazil in 2005. A reliability approach utilizing the aid of Microsoft Excel Visual Basic (VBA) was performed, utilizing Monte Carlo simulations. A semiempirical model based on fib (2006) was applied. The results show an inadequate serviceability of the pier during its design life. It was noticed the probability of corrosion initiation is highly dependent on surface chloride concentration. These results utilizing data from 2010 imply that early maintenance of marine structures can be more economical, but new measurements of the surface chloride concentration would imply different results. This paper is a benchmark for future design of marine structures.
\end{abstract}

Keywords: Reinforced Concrete Structures; Chloride corrosion; reliability; Monte Carlo.

\section{Probabilidade de início de corrosão por cloretos em estruturas de concreto armado - Estudo de caso de um píer no Brasil}

\section{RESUMO}

Este estudo de caso pretende estimar a probabilidade de início de corrosão por cloretos ao longo do tempo em um píer de concreto armado construído no Brasil em 2005. Foi realizada uma 
abordagem de confiabilidade utilizando simulações de Monte Carlo, implementadas por meio de Visual Basic (VBA). Um modelo semi-empírico baseado em fib (2006) foi aplicado. Os resultados ilustram uma inadequada serviceabilidade do píer durante a sua vida útil. Percebeu-se que a probabilidade de início da corrosão é altamente dependente da concentração superficial de cloretos. Esses resultados utilizando dados de 2010 mostram que a manutenção antecipada de estruturas marinhas pode ser mais econômica mas novas medições da concentração de cloretos na superfície implicariam resultados diferentes. Este documento é uma referência para o futuro projeto de estruturas marinhas.

Palavras chave: Estruturas de Concreto Armado; Corrosão por cloretos; confiabilidade; Monte Carlo.

\section{INTRODUCTION}

According to NACE (2016), the global cost of corrosion is estimated to be $3.4 \%$ of the global Gross Domestic Product. Among the diverse structures affected by corrosion are reinforced concrete structures (RC), which are component of the majority of the world's infrastructure. In the past decades $\mathrm{RC}$ has become dominant in the construction of many structures such as bridges, piers, waterways and civil buildings (Howlander et al., 2013).

In RC structures there are two relevant forms of corrosion, one induced by atmospheric carbon dioxide and the other by free chlorides. Such process occurs by the break of the passivation film provided by the steel dioxide. This phenomenon of expansive characteristics can lead to the appearance of high tensions, originating cracks and later chipping of the concrete cover. All these factors may cause a loss of the cross section and adherence between the concrete cover and the steel, and, because of this condition, the tension transference amid the material is almost impossible, potentially causing the structure to collapse (Oliveira Andrade, 2001).

In this paper, the corrosion induced by chlorides will be targeted. This type of corrosion occurs due to the penetration of salt spray, almost always present in the atmosphere near marine construction, which characteristically provides chloride ions, aggressive to RC structures.

Although different forms of chloride contamination occurs, as the permeation of de-icing salts and the presence of chloride containing additives in the concrete mix (accelerators containing $\mathrm{CaCl}_{2}$ (calcium chloride)) (Bhargava et al., 2011), this study will be concerned with the direct contact of the concrete with seawater and its waves splashing that occurs in structures located on the seafront, as piers. Seafront structures are the most vulnerable to chloride-induced corrosion (Figueiredo, 2013).

The unfavorable relative humidity and temperature conditions, typical of tropical countries as Brazil, accelerates the chloride-induced corrosion process (El Hassan et al., 2010). Thus, in the wet and hot Brazilian coastal cities the risk of chloride induced corrosion is even higher.

Aggravating this fact, the maintenance of structures isn't ideal in Brazil, causing the early repair of many reinforced concrete structures. For this reason, projects involving construction in unfavorable conditions usually are more conservative, with higher compressive strength and lower water/cement ratio. Predicting the time to corrosion initiation when designing a RC structure could reduce the risk of corrosion initiation during service life dramatically and enable the designers to justify their approach, more or less conservative, in terms of compressive strength and water/cement ratio.

To provide a tool for the design process of reinforced concrete structures in marine environments, this paper, aided by a Monte Carlo based reliability study, demonstrate the application of time to corrosion initiation models by utilizing the data obtained from a pier constructed in 2005 in the coastal area of Brazil, as described by Araújo \& Panossian (2010) and seen in Figure 1. With the 
results generated it will be possible to assess if the pier under analysis was over or under designed.

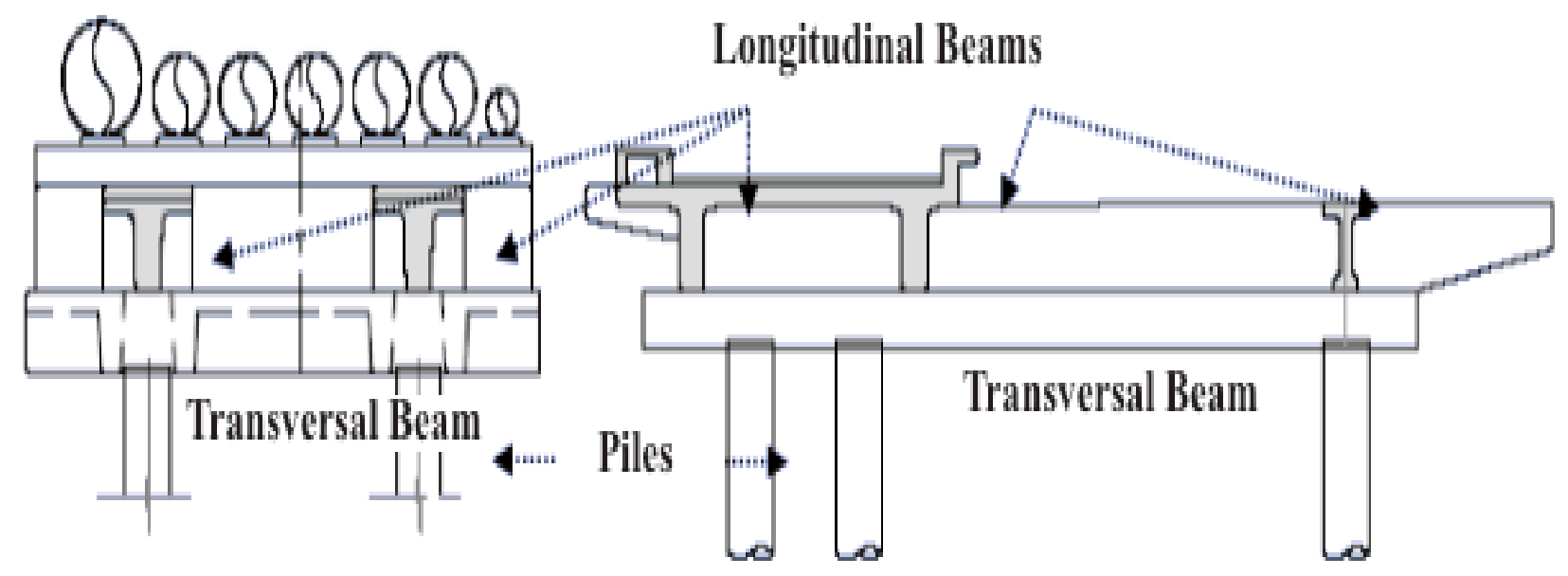

Figure 1. Schematic section of the pier analyzed. (adapted from Araújo \& Panossian, 2010).

\section{METHODS}

With the evolution that has happened in the past decades in diverse knowledge areas, the life span prediction of concrete structures related to the time to corrosion initiation can be estimated minimizing the inherent uncertainties of the results obtained.

In this study, the Monte Carlo simulation method was used. The Monte Carlo simulation method is a computerized mathematical technique that allows considering risk in quantitative analysis and decision-making. The use of Monte Carlo simulation is justified by the provisions it delivers to the user, as a range of possible outcomes and the probabilities of occurrences of these results according to the chosen action as a decision. It shows the extreme possibilities - the results of the boldest and the most conservative decisions - and all the possible consequences of more moderate decisions.

There are several models discussing chloride-induced corrosion, and these models can be divided into two groups. One group considers the interaction of chloride ions with another ions existent in the concrete interface and the other does not consider this phenomenon. Considering the interaction between chloride ions with other ions involves several implications, as taking into account the flux of different ions proposed by Nernst-Planck equation (Val \& Stewart, 2009). In addition, there are not sufficient data for the adequate and precise probabilistic use of these models due to the uncertainties related with the parameters considered in this group. The use of the second group is more frequent, because even considering parameters with relative uncertainties, such as the moisture diffusion, coupled chloride diffusion, heat transfer and chloride biding, this group is simpler and more easily handled. Nevertheless, the second group models are not very appropriate to the use of reliability analysis, such as in this study, mainly because of the lack of data yet present in this group (Val \& Stewart, 2009).

Consequently, among the existent models, this case study chose to utilize the models proposed by (fib, 2006), which are based on Fick's second law of diffusion. The model is based on this formula because of the characterization of the chloride migration as a pure diffusion process.

\subsection{Model description}


Although the referred model is a semi-empirical model, the results yielded are very accurate, as shown in Figure 2.

The model is described as follows.

$\frac{\partial C}{\partial t}=D \frac{\partial^{2} C}{\partial r^{2}}$

The life span prediction of reinforced concrete structures is commonly done by the measurement of percentages of chloride ions in specified depths in the structural element, in a certain amount of time of exposure $t$. With the resultant profile of chloride-penetration the total concentration of chloride ions (C) and the chloride diffusion coefficient (D) are obtained.

As (Val, 2012) stated, in order to fulfill the formulation of the problem, appropriate initial and boundary conditions are required to be specified, as seen in Equation 2.

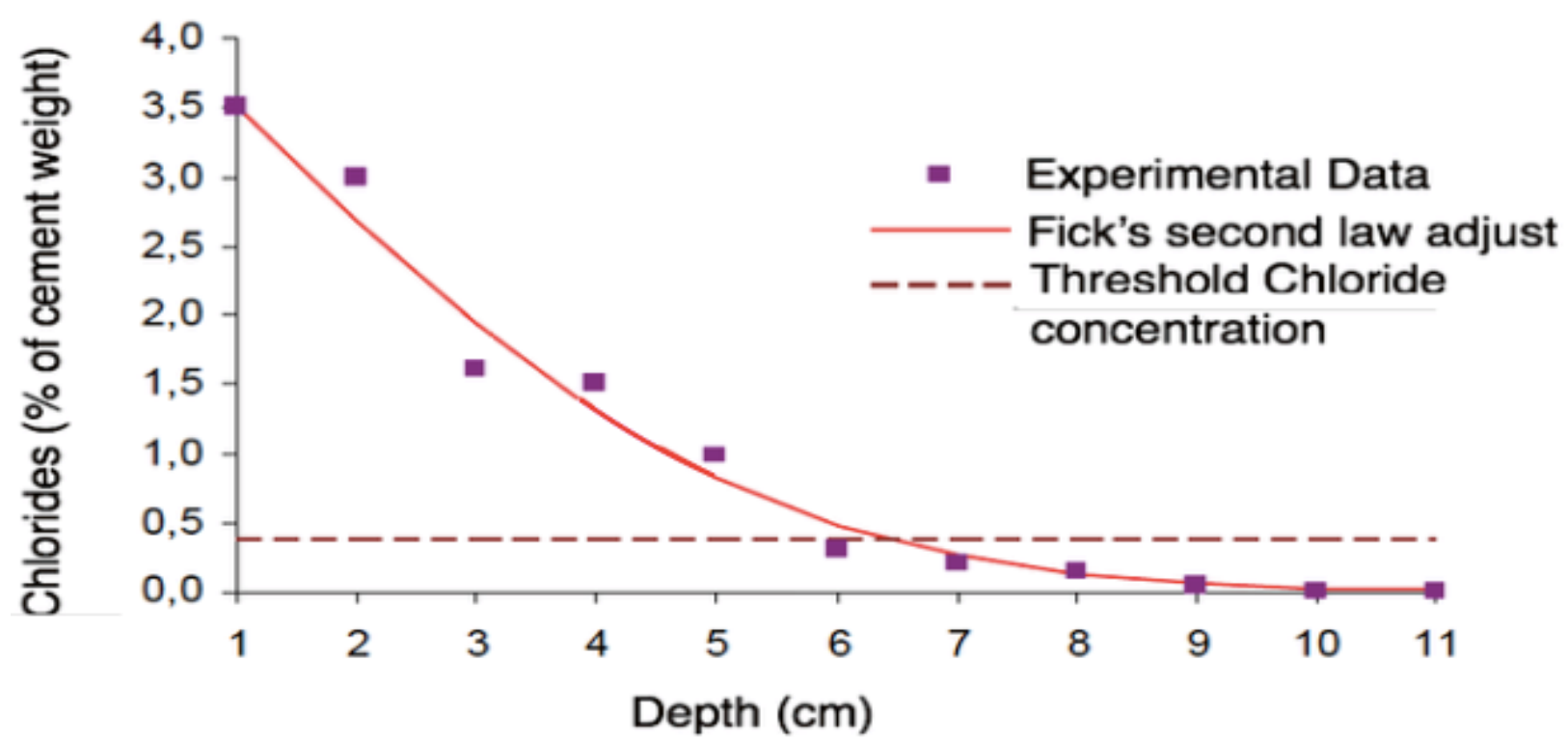

Figure 2. Typical chloride profile of a structure in time t. Adapted from (Oliveira Andrade, 2001).

$\mathrm{C}(\mathrm{x}>\Delta \mathrm{x}, \mathrm{t})=\mathrm{C}_{\mathrm{i}}(\mathrm{x})$

$\mathrm{C}(\Delta \mathrm{x}, \mathrm{t}>0)=\mathrm{C}_{\mathrm{s}, \Delta \mathrm{x}}(\mathrm{t})$

where:

$\Delta \mathrm{x}$ is the depth of the convection zone in centimeters (where Fick's second law is not considered);

$\mathrm{C}_{\mathrm{i}}(\mathrm{x})$ is the initial chloride concentration in $\%$; and

$\mathrm{C}_{\mathrm{s}, \Delta \mathrm{x}}(\mathrm{t})$ is the chloride concentration at depth $\Delta \mathrm{x}$ in $\%$.

Boundary conditions also applied to the model are the assumptions that the concrete element is a homogeneous, semi-infinite medium and isotropic material, and that chlorides and concrete components do not interact when chloride penetration occurs. (Oliveira Andrade, 2001)

The surface chloride concentration and the chloride diffusion coefficient may change with time. However, $\mathrm{C}_{\mathrm{s}}$ is not assumed to depend on time because its variations normally occur in brief periods of time, therefore for long term predictions, as the one approached in this study, $\mathrm{C}_{\mathrm{s}}$ can be 
considered constant. As (Maage et al., 1996) suggested, the time-reliance of the chloride diffusion coefficient is

$\mathrm{D}_{\mathrm{a}}(\mathrm{t})=\mathrm{D}_{\mathrm{a}, \mathrm{ref}}\left(\frac{t_{\mathrm{ret}}}{t}\right)^{m}$

where:

$\mathrm{D}_{\mathrm{a}}$ is the apparent diffusion coefficient;

$\mathrm{D}_{\mathrm{a}, \mathrm{ref}}$ is the apparent diffusion coefficient at a reference time $t_{\text {ref; }}$ and $\mathrm{m}$ is the age factor.

$\mathrm{D}_{\mathrm{a}, \mathrm{ref}}$ can be estimated as suggested by (fib, 2006):

$\mathrm{D}_{\mathrm{a}, \mathrm{ref}}=\frac{1}{1-m} k_{\mathrm{T}} D \mathrm{RCM}, \mathrm{c}$

where:

$\mathrm{k}_{\mathrm{T}}$ is a temperature parameter; and

$\mathrm{D}_{\mathrm{RCM}, 0}$ is the reference value found by the Rapid Chloride Migration (RCM) method (Val, 2012). $\mathrm{k}_{\mathrm{T}}$ is described by the Arrhenius equation

$\mathrm{k}_{\mathrm{T}}=\exp \left(b T\left(\frac{1}{T_{\text {ref }}}-\frac{1}{T}\right)\right)$

where:

$\mathrm{b}_{\mathrm{T}}$ is the regression parameter;

$\operatorname{Tr}_{\text {ef }}$ the reference temperature $(293 \mathrm{~K})$; and

$\mathrm{T}$ is the ambient temperature.

The apparent diffusion coefficient is an average diffusivity over a time amount $t$, not representing a physical property of the concrete element over this period t. Since the chloride is assumed to remain constant with time, Eq. (1) can be solved by the combination of the description Eq. (3) providing

$\mathrm{C}(\mathrm{x}, \mathrm{t})=\mathrm{C}_{\mathrm{i}}+\left(\mathrm{C}_{\mathrm{s}, \Delta \mathrm{x}}-\mathrm{C}_{\mathrm{i}}\right) \operatorname{erf}^{C}\left(\frac{x-\Delta x}{2 \sqrt{t D \mathrm{a}(t)}}\right)$

where:

$\mathrm{D}_{\mathrm{a}}(\mathrm{t})$ is the apparent diffusion coefficient in $\mathrm{cm}^{2} /$ year; and erfc is the Gaussian error function complement.

It is important to note that $\mathrm{D}_{\mathrm{a}}(\mathrm{t})$ not only depends on time, but also on temperature, as seen in Equation 5.

The model for estimation of the probability of corrosion initiation in this study is the one suggested by (Val \& Trapper, 2008)

$\mathrm{P}_{\text {corrosion }}(\mathrm{t})=$ Probability $\left[\mathrm{C}_{\text {crit }}-\mathrm{C}(\mathrm{x}=c, \mathrm{t})<0\right]$

where:

$\mathrm{P}_{\text {corrosion }}$ is the probability of corrosion initiation;

$\mathrm{C}_{\text {crit }}$ is the threshold chloride concentration; and

$c$ is the depth of the concrete cover. 
As previously mentioned, the model is applied by utilizing the resources of Monte Carlo simulation, in this study implemented by the Visual Basic tool of Microsoft Excel. Hence, each parameter used is further explained and described as a random variable or a deterministic value.

\subsubsection{Description of the model parameters}

\subsubsection{The reference value found by the $R C M$ method, $D_{R C M, 0}$}

Ideally, this parameter should be found by utilizing the RCM method. However, in this case study, this information was not possible to encounter. Thus, the following table, as described in (fib 2006), can be used for guidance.

Table 1. $\mathrm{D}_{\mathrm{RCM}, 0}$ mean values, specified for each concrete type. Adapted from fib (2006)

\begin{tabular}{|c|c|c|c|c|c|c|}
\hline \multirow{3}{*}{ Type of cement } & \multicolumn{6}{|c|}{$\mathrm{D}_{\mathrm{RCM}, 0}$ in $10^{-12}\left(\mathrm{~m}^{2} / \mathrm{s}\right)$} \\
\hline & \multicolumn{6}{|c|}{ water/cement $\mathrm{EQv}^{1}$} \\
\hline & 0.35 & 0.40 & 0.45 & 0.50 & 0.55 & 0.60 \\
\hline CEM I 42.5 R & n.d $d^{2}$ & 8.9 & 10.0 & 15.8 & 19.7 & 25.0 \\
\hline CEM I $42.5 \mathrm{R}+\mathrm{A}(\mathrm{k}=0.5)$ & n.d $\mathrm{d}^{2}$ & 5.6 & 6.0 & 0.0 & 10.9 & 14.9 \\
\hline CEM I $42.5 \mathrm{R}+\mathrm{A}(\mathrm{k}=2.0)$ & 4.4 & 4.8 & n.d $\mathrm{d}^{2}$ & n. $d^{2}$ & 5.3 & n. $\mathrm{d}^{2}$ \\
\hline CEM III/B 42.5 & n.d $d^{2}$ & 1.4 & 1.9 & 2.8 & 3.0 & 3.4 \\
\hline
\end{tabular}

${ }^{1}$ equivalent water/cement ratio, considering silica fume (SF) or fly ash (FA) with the respective efficiency factors (k-values). The considered contents were: FA - 22\% of cement weight and SF $-5 \%$ of cement weight.

${ }^{2}$ n.d. - there are not available data on $\mathrm{D}_{\mathrm{RCM}, 0}$ for these types of cement.

It is advisable that $\mathrm{D}_{\mathrm{RCM}, 0}$ is measured after 28 days $\left(0.0767\right.$ years, $\mathrm{t}_{\text {ref }}=28$ days). The $\mathrm{D}_{\mathrm{RCM}, 0}$ is assumed to be normally distributed with a coefficient of variation (COV) of 0.2.

\subsubsection{The age factor, $m$}

The age factor $m$ is described by a Beta distribution on the interval $[0,1.0]$. Its values depend on the time and conditions of exposure and the concrete composition. The values of the mean and coefficient of variation of the age factor $m$ for reinforced concrete structures are different depending on the zone in which the concrete is exposed (submerged, tidal and splash zones); these values are presented in Table 2. The $m$ values are derived from Equation (4) by replacing the $\mathrm{D}_{\mathrm{RCM}, 0}$ value found by the RCM method in a direct form, referring to different values of $\mathrm{Da}$, at specific points in time. Taking into consideration this fact, the $1 /(1-\mathrm{m})$ factor does not appear in Equation (4) when performing the Monte Carlo simulation (Val, 2012).

Table 2. Coefficient of variation (COV) and mean of the age factor $m$. Extracted from (Val, 2012)

\begin{tabular}{|c|c|c|}
\hline Type of cement & Mean & COV \\
\hline $\begin{array}{c}\text { Ordinary Portland Cement (OPC) } \\
\text { CEM I; }\end{array}$ & & \\
$0.40 \leq w / c \leq 0.60$ & 0.3 & 0.4 \\
\hline $\begin{array}{c}\text { OPC with fly ash (FA) CEM I + } \\
\text { FA; FA } \geq 20 \% \text { weight of cement; } \\
0.40 \leq w / \text { ceqv } \leq 0.6 C\end{array}$ & 0.6 & 0.25 \\
\hline Blast furnace slag cement (GBFS) & 0.45 & \\
\hline
\end{tabular}




\section{CEM III/B; \\ $0.40 \leq w / c \leq 0.60$}

0.44

\subsubsection{The regression parameter, $b T$}

The regression parameter $b_{T}$, needed for Equation (5), is adequately described by a normal distribution with mean of $4800 \mathrm{~K}$ and a coefficient of variation of 0.146 .

\subsubsection{The threshold chloride concentration, Ccrit}

The threshold chloride concentration $\mathrm{C}_{\text {crit }}$, needed for Equation (7), is adequately described by a Beta distribution on the interval $[0.2,2.0]$ weight of cement with mean of 0.6 weight of cement and a coefficient of variation of 0.25 . NBR 12655 describes it as deterministic, with a maximum value of 0.15 .

\subsubsection{The thickness of the concrete cover, $c$}

The thickness of the concrete cover $c$ is adequately described by a lognormal distribution with mean equal to its defined nominal value and standard deviation depending on the execution requirements. If it does not need additional requirements, its coefficient of variation is in the range of $8-10 \mathrm{~mm}$; if it needs additional requirements, in places such as the splash zone, its standard deviation is $6 \mathrm{~mm}$.

\subsubsection{The depth of the convection zone, $\Delta x$}

The depth of the convection zone $\Delta \mathrm{x}$, needed for Equation (6), is adequately described by a Beta distribution on the interval $[0,50.0] \mathrm{mm}$ with a mean of $0.9 \mathrm{~mm}$ and a coefficient of variation of 0.60 for the splash zone. For the submerged zone and the atmospheric zone, $\Delta x$ can be treated as a deterministic parameter equal to 0 . For the tidal zone, there is not sufficient information in order to give it an estimative.

\subsubsection{The chloride concentration at depth $\Delta x, C s, \Delta x$}

The chloride concentration at depth $\Delta \mathrm{x}, \mathrm{C}_{\mathrm{s}, \Delta \mathrm{x}}$, when the source of chlorides is sea water, as in this case study, relies on several factors, as geographical location, zone type, height above sea level, dominant wind directions among others. Therefore, as used in this case study, local data is of very importance in order to perform an accurate simulation.

\subsection{Monte Carlo simulations}

This case study took into consideration, as previously stated, a Brazilian pier located in the coastal area of the country (Figure 1). While the pier has already been concluded, there were sufficient data to assess the analysis of the probability of corrosion initiation over time by Monte Carlo simulations. By this estimation done in VBA, it was possible to assess if the structure was properly designed regarding corrosion resilience.

Before performing the simulations, the parameter choice has to be made.

Besides the parameters input values described in section 2.1.1, there are parameters which were derived on the local data of the pier, described by Araújo \& Panossian (2010), as the chloride surface concentration $\mathrm{C}_{\mathrm{s}}$, the thickness of the concrete cover $\mathrm{c}$, the chloride concentration at depth $\mathrm{C}_{\mathrm{s}, \Delta \mathrm{x}}$, the reference value found by the RCM method, DRCM, 0 and the age factor $m$.

The piles were in the splash zone and subjected to marine salt spray, the transversal beams were under weathering and in contact with draining and condensing seawater. The construction of the 
pier followed the Brazilian norms NBR 6118 and NBR 12655 and for clarification the parameters for each norm are stated in Table 3.

Table 3. Brazilian Regulative Norms concerning Reinforced Concrete structures under marine conditions. Adapted from (Araújo \& Panossian, 2010)

\begin{tabular}{|c|c|c|c|c|}
\hline \multirow{2}{*}{ Norm } & \multicolumn{4}{|c|}{ Parameter } \\
\cline { 2 - 5 } & w/c ratio & $\begin{array}{c}\text { fck } \\
(\mathbf{M P a})\end{array}$ & $\begin{array}{c}\text { Chloride content } \\
\text { (\% weight of cement) }\end{array}$ & $\begin{array}{c}\mathbf{c}^{\mathbf{2}} \\
(\mathbf{c m})\end{array}$ \\
\hline NBR 6118 & $\leq 0.45$ & $\geq 40$ & - & 5.0 \\
\hline NBR 12655 & $\leq 0.40$ & $\geq 45$ & $\leq 0.15$ & - \\
\hline
\end{tabular}

${ }^{1} \mathrm{w} / \mathrm{c}$ is water cement ratio

${ }^{2} \mathrm{c}$ is the thickness of the concrete cover

In the Excel $V B A$ program, for the atmospheric zone conditions, the simulations were performed utilizing the transversal beams data. The concrete cover utilized was $0.05 \mathrm{~m}$; the chloride concentration at the surface of the beams had a mean of $1.36 \%$, percentage relative to the weight of cement. As the water/cement ratio used was 0.45 and the cement type considered was the CEM I 42.5 R, its correspondent chloride migration coefficient, $D_{R C M, 0}$, was $10^{-11} \mathrm{~m}^{2} / \mathrm{s}$. With these conditions, the age factor had a mean of 0.3 with a standard deviation of 0.12 . The threshold chloride concentration, Ccrit was firstly based on 2.1.1.4 and later based on NBR 12655.

For the splash zone conditions, the simulations were performed utilizing the piles data. The concrete cover utilized was $0.055 \mathrm{~m}$; the chloride concentration at the surface had a mean of $0.95 \%$ (Araújo \& Panossian, 2010), percentage relative to the weight of cement. As the water/cement ratio used in the pier's structures was 0.45 and the cement type considered was the CEM I 42.5 R, its correspondent chloride migration coefficient, $D_{R C M, 0}$, was $10^{-11} \mathrm{~m}^{2} / \mathrm{s}$. With these conditions, the age factor had a mean of 0.3 with a standard deviation of 0.12 . The threshold chloride concentration, Ccrit was firstly based on 2.1.1.4 and later based on NBR 12655 .

\section{RESULTS}

After utilizing Excel $V B A$ to implement the model performing the Monte Carlo simulation method utilizing the data provided, the graphs of the Figures 3, 4, 5, 6, 7, 8, 9 and 10 were generated. 


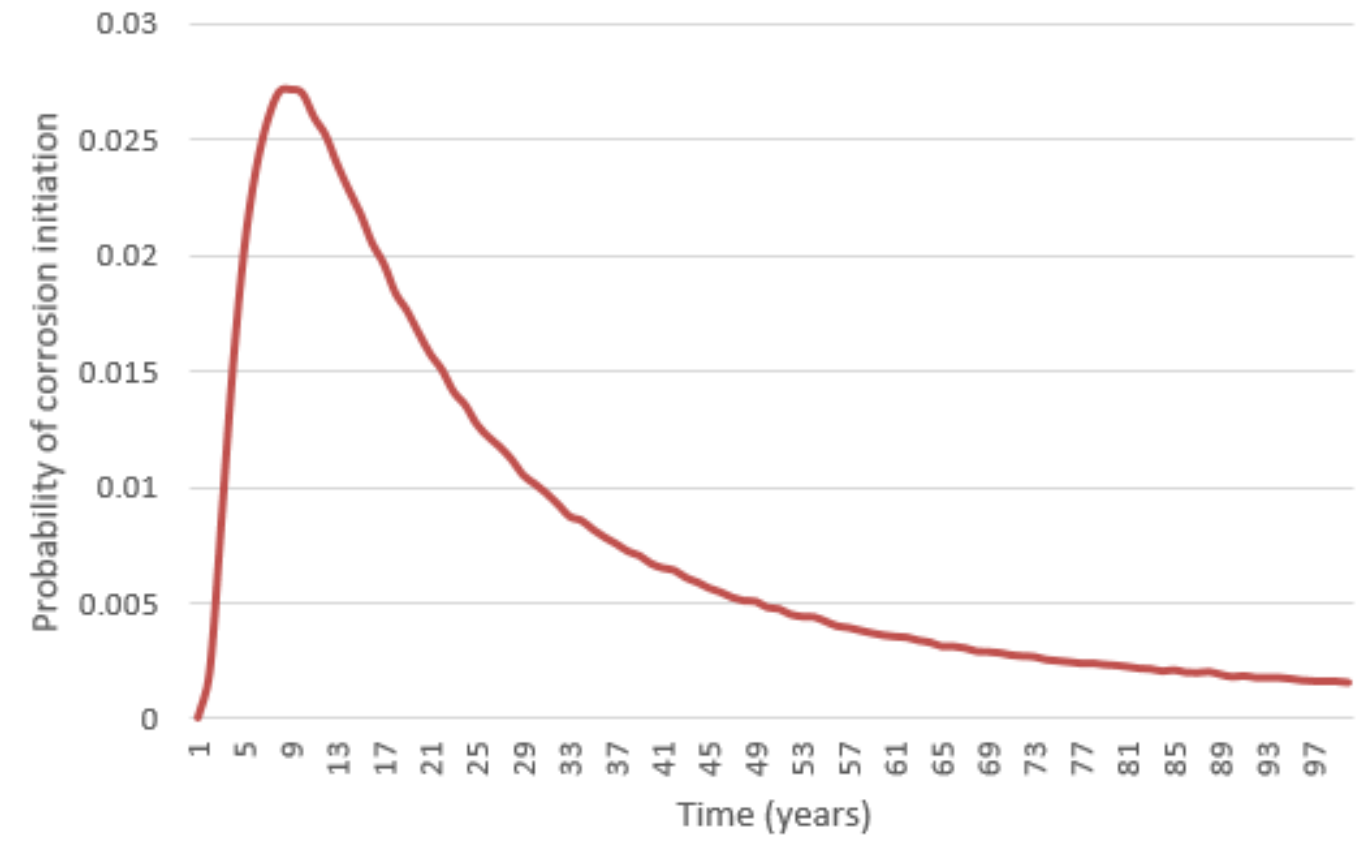

Figure 3. Annual probability of corrosion over time in years for the transversal beams in atmospheric zone conditions, adopting Ccrit from 2.1.1.4

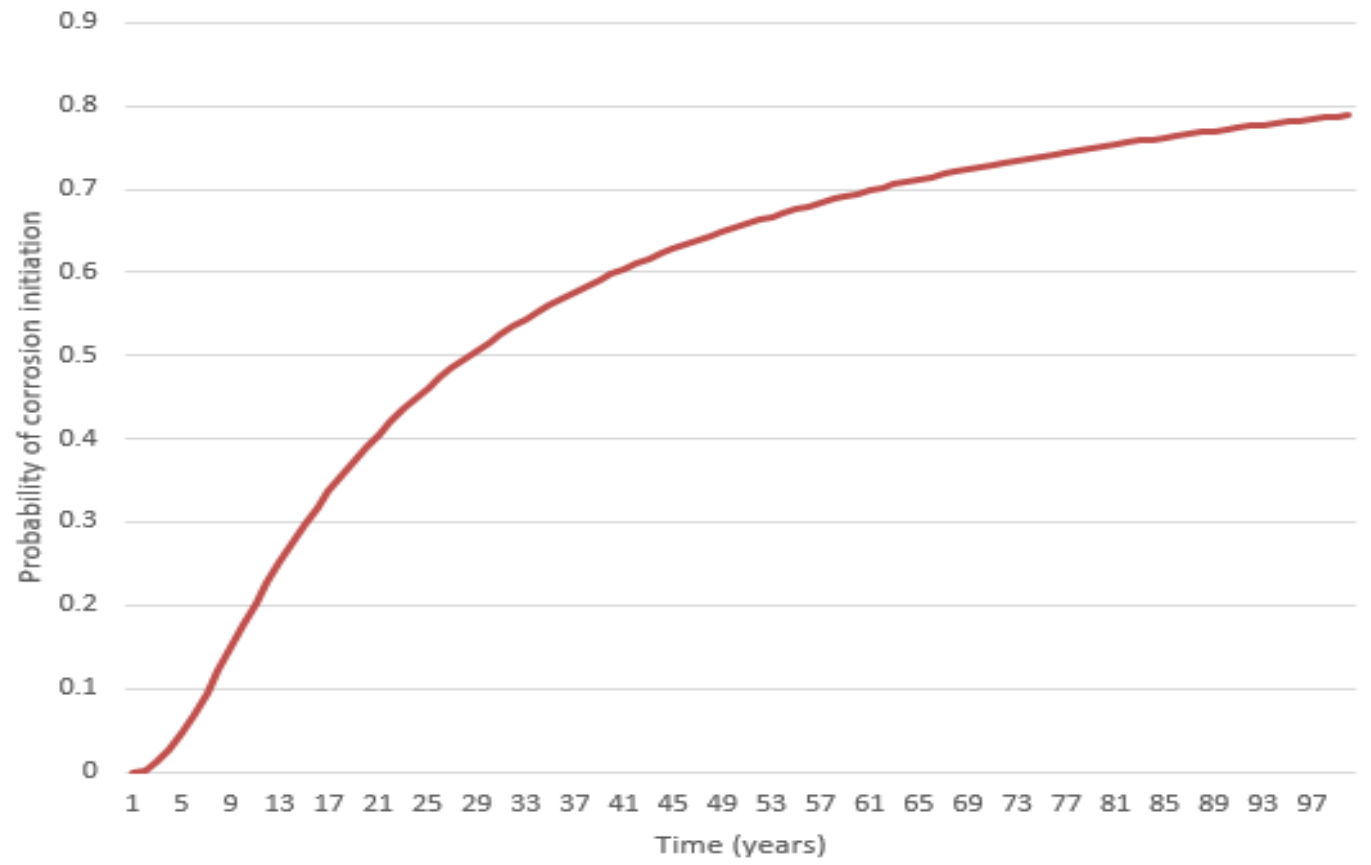

Figure 4. Cumulative probability of corrosion over time in years for the transversal beams in atmospheric zone conditions, adopting Ccrit from 2.1.1.4 


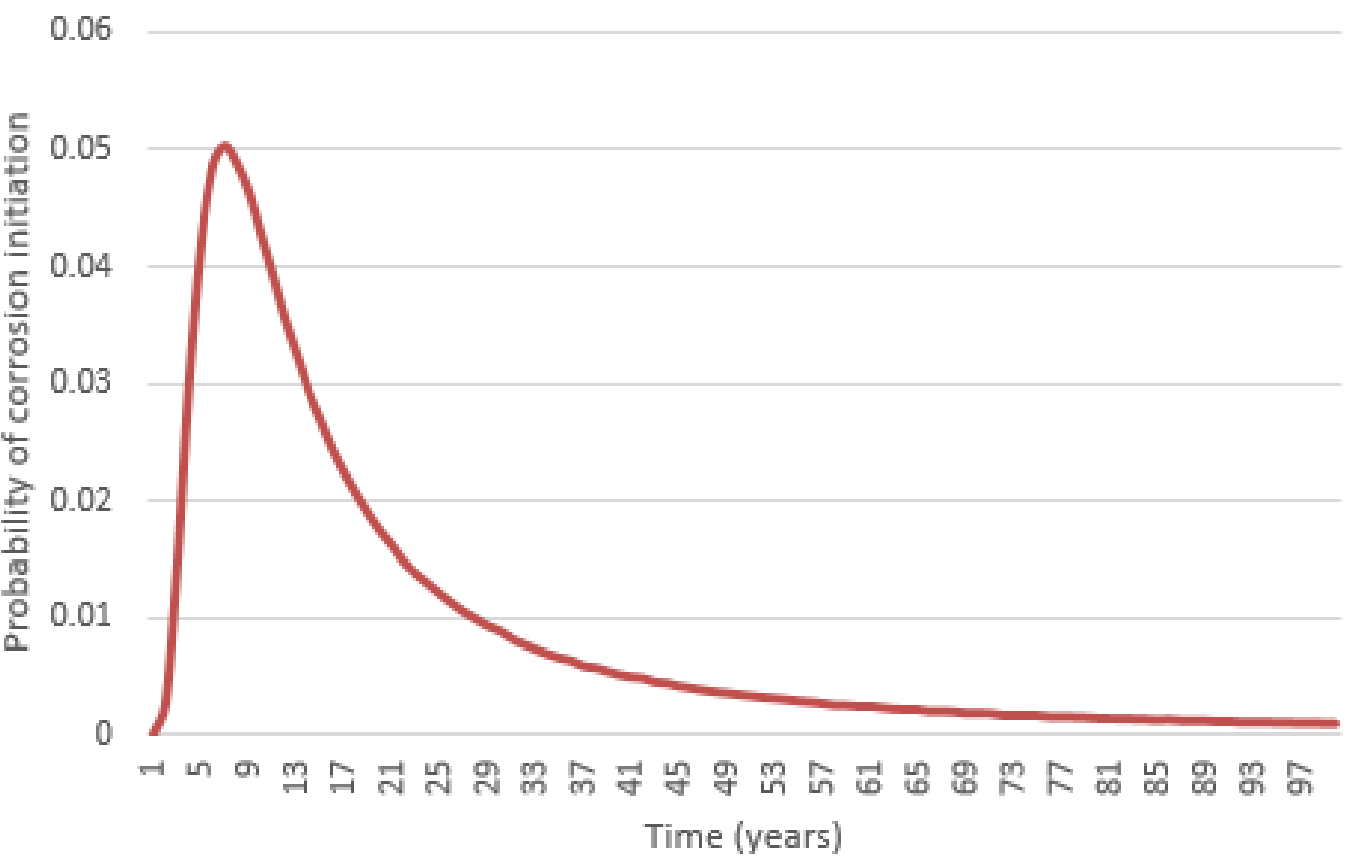

Figure 5. Annual probability of corrosion over time in years for the transversal beams in atmospheric zone conditions, adopting Ccrit from NBR 12655

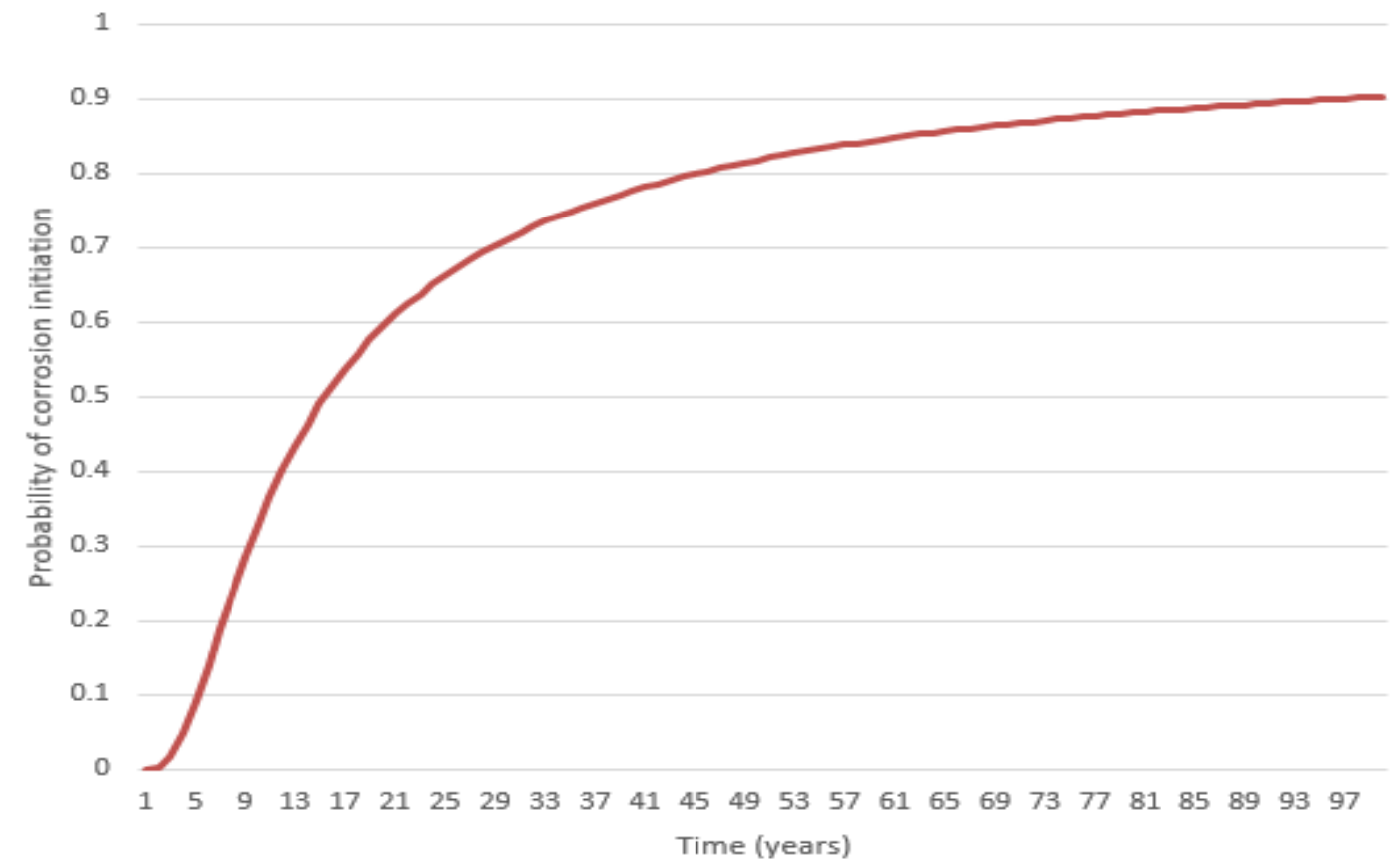

Figure 6. Cumulative probability of corrosion over time in years for the transversal beams in atmospheric zone conditions, adopting Ccrit from NBR 12655 


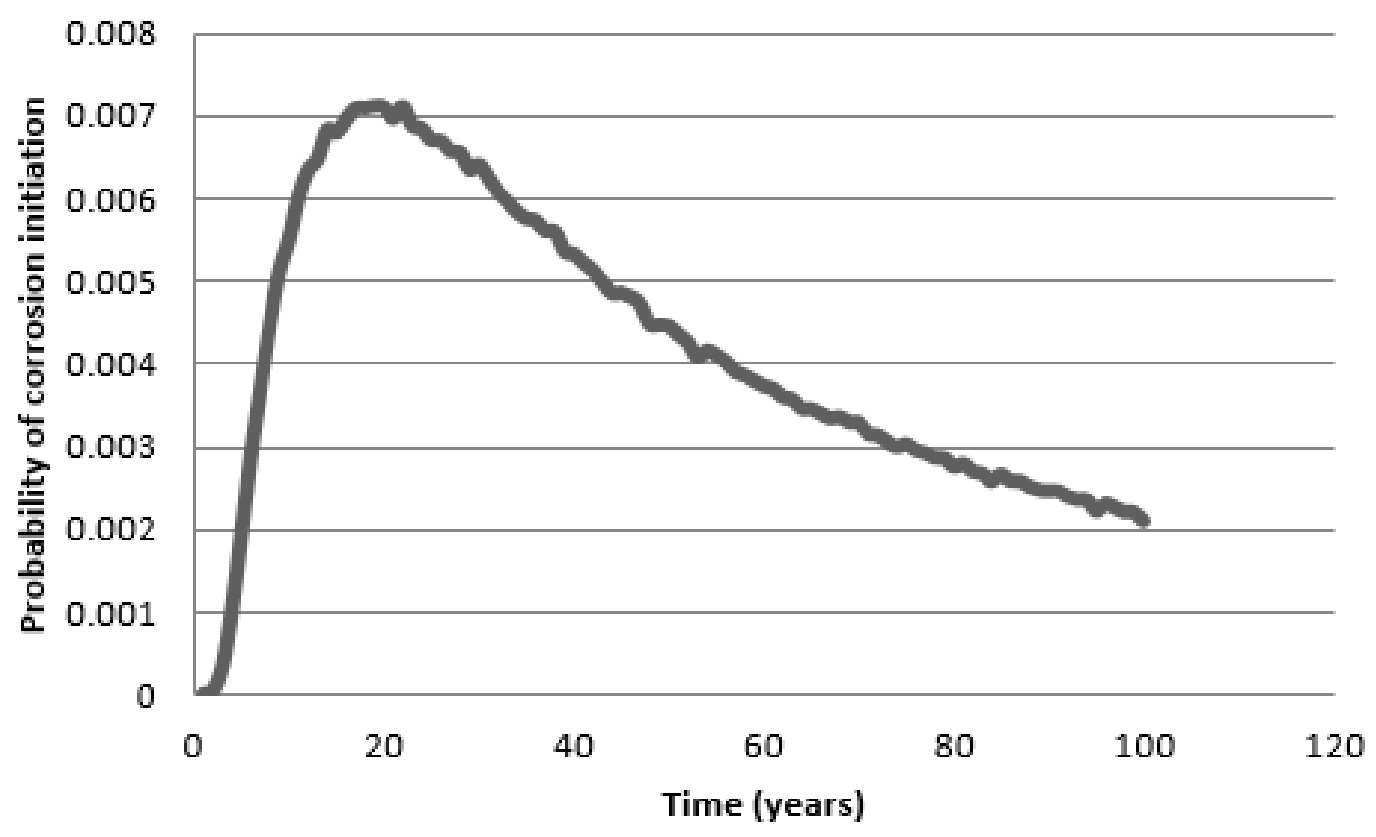

Figure 7. Annual probability of corrosion over time in years for the piles in splash zone conditions, adopting Ccrit from 2.1.1.4

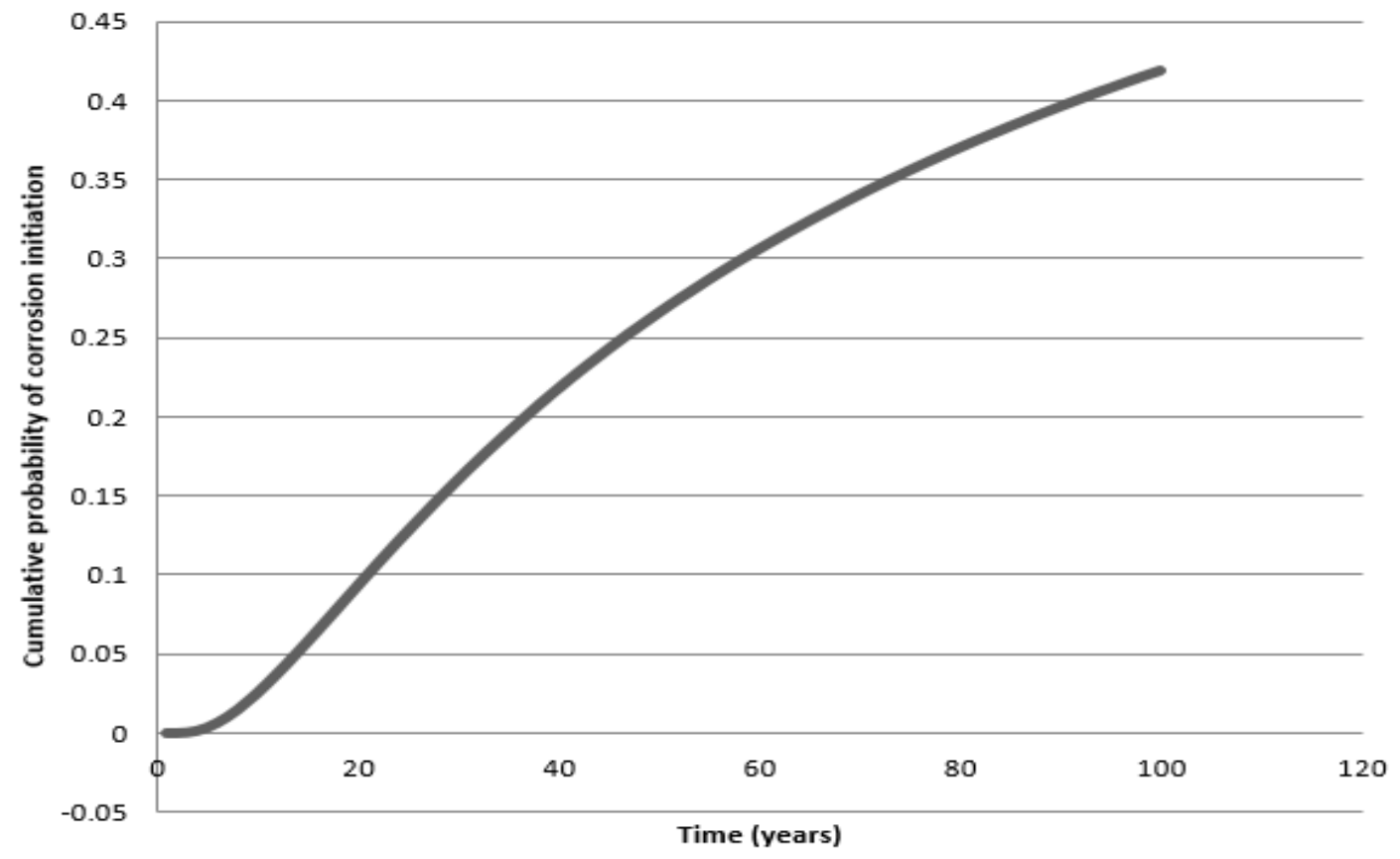

Figure 8. Cumulative probability of corrosion over time in years for the piles in splash zone conditions, adopting Ccrit from 2.1.1.4 


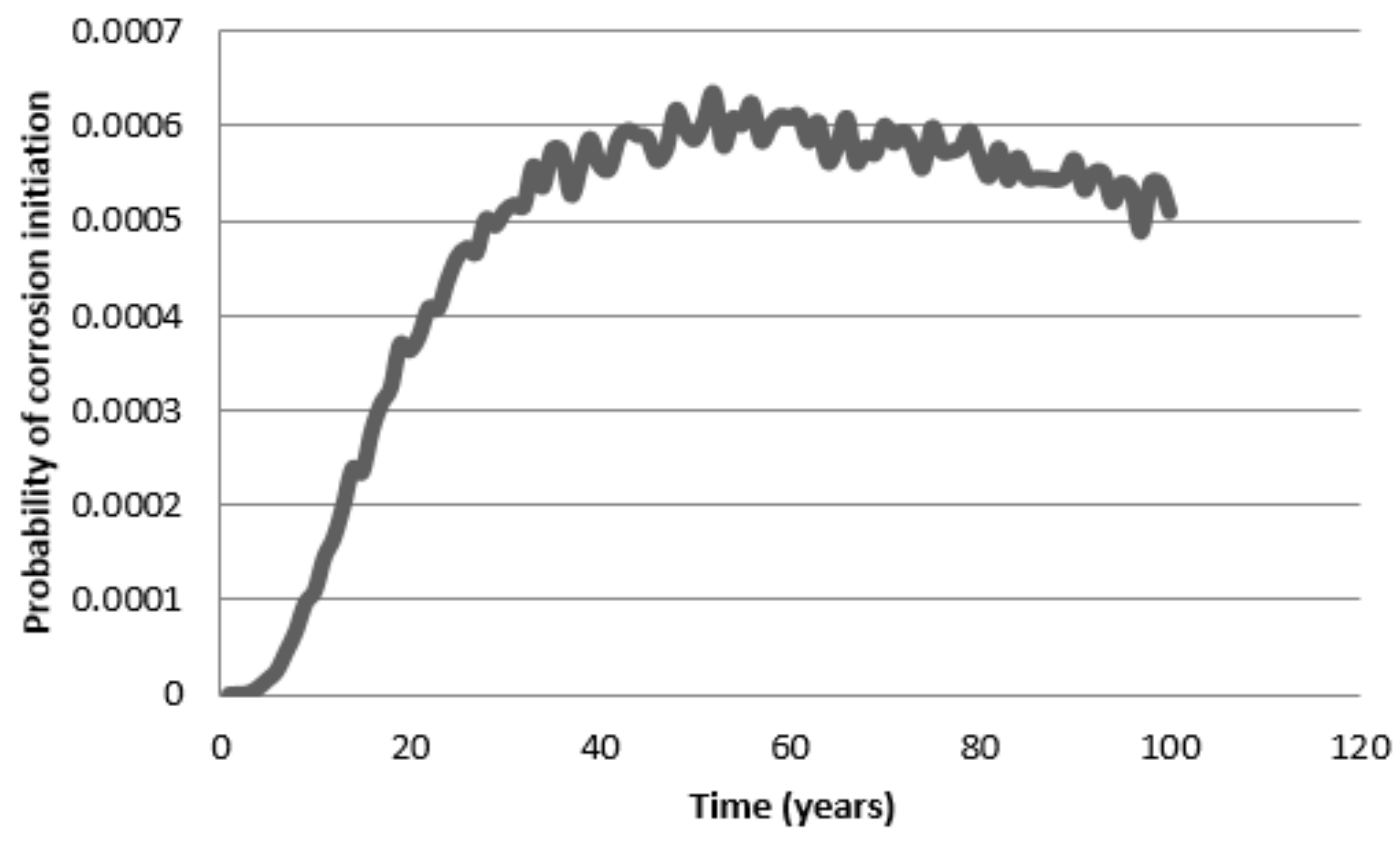

Figure 9. Annual probability of corrosion over time in years for the piles in splash zone conditions, adopting Ccrit from NBR 12655

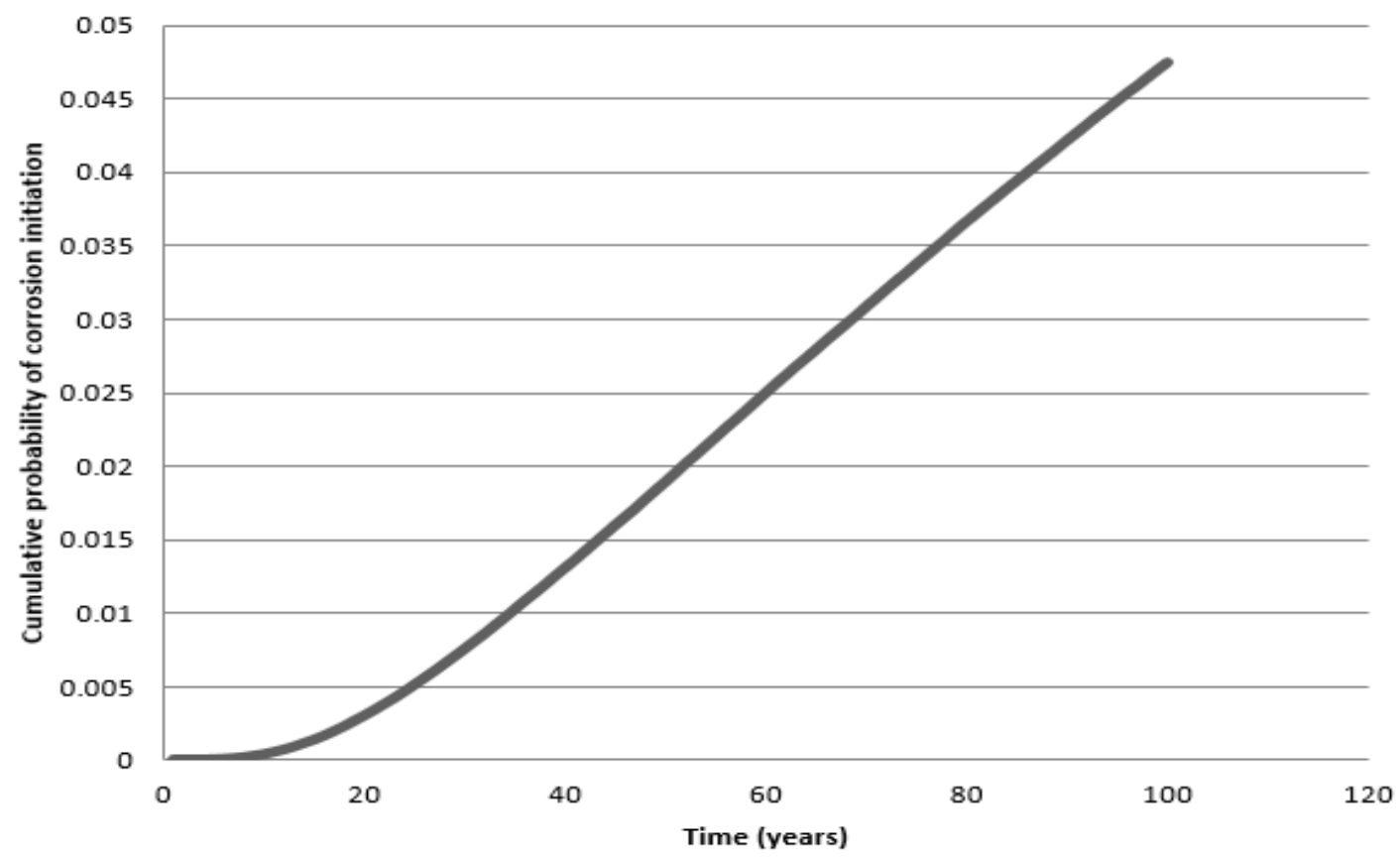

Figure 10. Cumulative probability of corrosion over time in years for the piles in splash zone conditions, adopting Ccrit from NBR 12655

\section{DISCUSSION}

In Figure 3 is presented the probability to corrosion initiation on the transversal beams in each year. In the graph, the probability of corrosion initiation was found by dividing the number of failures encountered in the simulations by the number of trials of Monte Carlo simulation. In this case study, the number of trials utilized was 10000000, since the random error term tends to zero as the simulations tend to infinity (Bucher \& Frangopol, 2006). 
Observing Figure 4 it is possible to notice the cumulative probability of corrosion initiation over 100 years, with preference to observe the first 50 years, since it was the projected life span of the pier. The cumulative probability of corrosion initiation in the first 50 years is $65 \%$, much higher than the limit of $6.7 \%$ for irreversible limit state (BSI, 2002). Regarding Figure 6, this probability is even higher, $82 \%$, due to the lower tolerance of the threshold chloride concentration of NBR 12655.

Similarly, in Figures 8 and 10, it is also possible to assess the cumulative probability of corrosion initiation over 100 years, rather the life span of the pier. Figure 8 presented $25 \%$ of cumulative probability of corrosion initiation in the first 50 years, and Figure 10 presented 1,9\%. Although the splash zone is usually considered more critical, it was found the cumulative probability of corrosion initiation in the first 50 years was lower than in the atmospheric zone simulations, for both values of threshold chloride concentration adopted, mainly due to the lower surface chloride concentration found in the piles.

These patterns found in the simulations indicates the dependency of probability to corrosion initiation on the local surface chloride concentration. It was noticeable from Figures 3 to 10 the results were very sensible of local measurements of chloride surface concentration, indicating that corrective measures of reducing surface chloride concentration early in the transversal beams and the piles are recommended to lower the probability of corrosion initiation and enhance the life span of the structure. As of 2010, when the measurements were made (Araújo \& Panossian, 2010), if there aren't measures for reducing the surface chloride concentration, the $6.7 \%$ limit imposed by BSI (2002) suggests a corrosion initiation of less than 10 years for the transversal beams, with both threshold chloride concentrations considered and less than 20 years for the piles, with the threshold chloride concentration from 2.1.1.4.

\section{CONCLUSIONS}

This paper reported a brief overview on the mechanisms of chloride-induced corrosion and its impacts on reinforced concrete structures in a marine environment, by a case study of a pier in Brazil regarding the probability to chloride-induced corrosion initiation, utilizing Monte Carlo simulations. Based on the results obtained in this paper, the following conclusions can be drawn:

1. The pier studied has a high probability of corrosion initiation during its service life, especially in the transversal beams.

2. The limits of NBR 12655 are stricter than the international standards regarding threshold chloride concentration.

3. Early repair aimed at reducing surface chloride concentration in beams can be effective in raising the life expectancy of the structure, as surface chloride concentration greatly impacts the probability of corrosion initiation.

\section{REFERENCES}

Araújo, A. \& Panossian, Z. (2010). "Durabilidade de estruturas de concreto em ambiente marinho: estudo de caso”, INTERCORR, 39p. 
Bhargava, K., Mori, Y., Ghosh. A.K. (2011). “Time-dependent reliability of corrosion-affected $R C$ beams. Part 3: Effect of corrosion initiation time and its variability on time-dependent failure probability”, Nuclear Engineering and Design 241, pp. 1395-1402.

BSI. (2002). BS EN 1990: 2002: Eurocode-Basis of structural design, pp. 95.

Bucher, C. \& Frangopol, D. M. (2006). "Optimization of lifetime maintenance strategies for deteriorating structures considering probabilities of violating safety, condition, and cost thresholds", Probabilistic Engineering Mechanics 21, pp. 1-8.

El Hassan, J., Bressolette, P., Chateauneuf A., El Tawil, K. (2010). "Reliability-based assessment of the effect of climatic conditions on the corrosion of RC structures subject to chloride ingress", Engineering Structures, Volume 32, Issue 10, pp. 3279-3287.

fib (2006). "Bulletin 34: Model Code for Service Life Design", International Federation for Structural Concrete, $116 \mathrm{p}$.

Howlander M. K., Rashid, M. H., Alam, Z. (2013). "Effect of Saline Water on the Flexural Performance of Ferrocement Wall Panel" International Journal of Advanced Structures and Geotechnical Engineering, Vol. 02, No. 03, 6p.

Maage, M., Helland, S., Poulsen, E., Vennesland, O., Carlsen, J.E. (1996) "Service life prediction of existing concrete structures exposed to marine environment", ACI Materials Journal, Vol. 93 (6), 602-608.

Oliveira Andrade, J. J. "Contribuição à previsão da vida útil das estruturas de concreto armado atacadas pela corrosão de armaduras: iniciação por cloretos”, PhD Thesis, UFRGS, (2001), $277 \mathrm{p}$.

Figueiredo, E.J.P. \& Meira, G.R. (2013). “Corrosão das armaduras de concreto” Alconpat. 6, p18-19.

NACE. (2016). "IMPACT - International measures of prevention, application and economics of corrosion technologies study” NACE International. pp 3-4.

Val, D. \& Stewart, M. G. (2009), "Reliability assessment of ageing reinforced concrete structures - current situation and future challenges", Structural Engineering International, vol 19, no. 2, pp. 211-219.

Val, D. \& Pavel A. Trapper. (2008). "Probabilistic evaluation of initiation time of chlorideinduced corrosion” Reliability Engineering \& System Safety, Volume 93, Issue 3, pp. 364-372. 